\title{
Association between PTX3 and PVT1 genetic polymorphisms and the risk of diabetic kidney disease in type 2 diabetic patients
}

\author{
Sindhu Varghese and Gowtham Kumar Subburaj
}

\begin{abstract}
Background: Very few studies have investigated the role of PTX3 and PVT1 genetic polymorphisms and their association in the progression of diabetic kidney diseases. Diabetic kidney disease (DKD) is a prominent reason of end-stage renal disease and also known to be involved in the high mortality rate of cardiovascular diseases. The current study has examined the role of PTX3 and PVT1 genetic polymorphisms in the development of diabetic kidney disease in type 2 diabetic patients.

Results: A significant difference between the genotypes and alleles of the rs2305619 polymorphism was observed in the diabetic patients with DKD when compared with the control group. The frequency of GG genotype was observed to be high in diabetic patients with DKD when compared to the other two groups. This specified that diabetic patients with GG genotype are at an increased risk to develop DKD. However, PVT1 (G/A) polymorphism did not show any association in the allele and genotypic frequencies with DKD when compared with T2DM and controls.
\end{abstract}

Conclusion: Our results propose a major influence of GG genotype of rs2305619 polymorphism to be significantly linked with an increased risk of DKD in type 2 diabetic patients.

Keyword: Gene polymorphism, T-ARMS PCR, Diabetic kidney disease, PTX3, PVT1

\section{Background}

Diabetes mellitus (DM) is associated with an extensive range of micro- and macrovascular problems along with some other metabolic problems [1]. Globally, it has become a major health concern as well as a substantial reason for morbidity and mortality [2]. Diabetic kidney disease (DKD) has become a prominent reason for kidney disease particularly in the subjects undergoing renal replacement therapy and it is also known to affect approximately $40 \%$ of T1DM and T2DM patients [3]. DKD is characterized by the occurrence of albumin creatinine

\footnotetext{
* Correspondence: gowtham_phd@yahoo.com
}

Faculty of Allied Health Sciences, Chettinad Hospital And Research Institute, Chettinad Academy of Research and Education (Deemed to be University), Kelambakkam, Tamil Nadu 603103, India ratio (ACR) at the rate of $>30 \mathrm{mg} / \mathrm{g}$ [4]. Genetic predisposition is an important aspect proved through family aggregation studies known to be associated with the progression of DKD in the context that not all patients with diabetes progress to kidney disease despite having poor glycaemic control for a long period [5, 6]. Several genes and their variants have been identified as associated with DKD in various populations.

Pentraxin 3 (PTX3) is known to be the only long pentraxin that can be identified in the tissues of the kidney $[7,8]$. The plasma levels of pentraxin 3 were identified to have an inverse link with eGFR which further exhibited a positive association with the levels of proteinuria in DKD patients [9]. As a direct consequence, it indicated the link of PTX3 in the development of diabetic 
kidney disease [10]. A distinct study, carried out in the Chinese population indicated the link between the genetic polymorphisms of PTX3 to have a predisposition in the diabetes patients with DN [11]. Another interesting fact is that various linkage studies have identified the chromosome $3 \mathrm{q}$ to be linked with diabetes and diabetic nephropathy in diverse ethnic populations, and PTX3 is also located at the location 3q25.32 [12]. The aforementioned statement further supports the relationship of PTX3 in the progression of DN.

Plasmacytoma variant translocation 1 gene (PVT1) is proved to have an influence on uncontrolled cell growth especially in the mesangial cell expansion which is identified to be an important hallmark in diabetic-related kidney diseases [13]. It is located at the chromosomal location 8q24 [14]. PVT1 gene is recognized to interfere at both the developing as well as the progression stage of DKD. A prominent point is that PVT1 is a substantial noncoding RNA which have an association with renal diseases [15]. A genome-wide association study carried out among the Pima Indians has shown a positive association of the genetic variant rs2648875 of PVT1 in endstage renal disease. An upregulation of PVT1 was seen which was instigated by the transforming growth factorbeta 1 (TGF $\beta 1$ ) as well as increased hyperglycaemic levels [16]. There are very few studies that are not enough to come to a final conclusion. Hence, further investigations in diverse ethnic populations are essential to discover relevant proof showing the link between genetic polymorphisms of $P V T 1$ in the progression of DN.

There are very few studies reported to date showing the association of PTX 3 and PVT1 with diabetic kidney disease. Besides, it should be noted that these two genetic polymorphisms show a positive link in the progression towards DKD in other populations. Hence, these two genetic variants were selected considering a strong ethnic heterogeneity.

\section{Aim}

The aim of the current study was to examine the association of PTX3 (rs2305619 A>G) and PVT1 (rs2648875 $\mathrm{G}>\mathrm{A})$ genetic polymorphisms with diabetic kidney disease in diabetic patients.

\section{Methods}

This present study was carried out from a period of November 2016 to December 2018. A written consent form was attained from all the subjects participated in the study. Overall 420 subjects were involved in the study of which, 140 patients with type 2 diabetes mellitus and DKD and 140 patients with type 2 diabetes mellitus without DKD were enrolled in the study. 140 healthy participants were involved in the study as controls.

The patients with type 2 diabetes mellitus were identified based on criteria chosen by the American Diabetes Association [17]. Whereas patients with diabetic kidney disease were determined by assessing the urinary albumin excretion level of $>30 \mathrm{mg} / \mathrm{g}$ in a 24-h urine collection and based on the KDOQI (Kidney Disease Outcomes Quality Initiative) guidelines [18]. In the present study protein creatinine ratio (PCR) was taken as a substitute for ACR because of non-albumin proteinuria was suspected. DKD patients were also confirmed with the manifestation of diabetic retinopathy. All the subjects for the study were selected on the basis of strict clinical examination. The participants selected as controls did not exhibit any clinical indication or past history of type 2 diabetes mellitus and kidney-related

Table 1 Designed primer sequences used in Tetra-Arms PCR genotyping

\begin{tabular}{|c|c|c|c|}
\hline Gene polymorphism & Primer sequence ( $5^{\prime}$ to $\left.3^{\prime}\right)$ & Melting temp. & Amplicon length \\
\hline \multirow[t]{4}{*}{$\begin{array}{l}\text { PTX3 (rs2305619) } \\
\text { A/G }\end{array}$} & $\begin{array}{l}\text { Forward outer primer } \\
\text { ACTCAGCTCACTTGAGAGTCTCCTCCCG }\end{array}$ & $66^{\circ} \mathrm{C}$ & \\
\hline & $\begin{array}{l}\text { Reverse outer primer } \\
\text { CGCCGGTTATGTAGCTCAAAACAGTCAA }\end{array}$ & $66^{\circ} \mathrm{C}$ & $439 \mathrm{bp}$ \\
\hline & $\begin{array}{l}\text { Forward inner primer (A allele) } \\
\text { CCATCCCACTGAGGACCGTAAGTGCA }\end{array}$ & $68^{\circ} \mathrm{C}$ & $255 \mathrm{bp}$ \\
\hline & $\begin{array}{l}\text { Reverse inner primer (G allele) } \\
\text { AGTCAGGGTTAGCAGAGAAACAGTTAACGC }\end{array}$ & $68^{\circ} \mathrm{C}$ & $230 \mathrm{bp}$ \\
\hline \multirow[t]{4}{*}{$\begin{array}{l}\text { PVT1 (rs2648875) } \\
\text { G/A }\end{array}$} & $\begin{array}{l}\text { Forward outer primer } \\
\text { GGTTACATGTGTAAGCTCATCCAATCCC }\end{array}$ & $64^{\circ} \mathrm{C}$ & \\
\hline & $\begin{array}{l}\text { Reverse outer primer } \\
\text { TAGTAGAGACGGGGTTTCACCATGTTAGC }\end{array}$ & $64^{\circ} \mathrm{C}$ & $390 \mathrm{bp}$ \\
\hline & $\begin{array}{l}\text { Forward inner primer (G allele) } \\
\text { GTAAGTCATTGGTCTITGCAGGTGATGA }\end{array}$ & $66^{\circ} \mathrm{C}$ & $239 \mathrm{bp}$ \\
\hline & $\begin{array}{l}\text { Reverse inner primer (A allele) } \\
\text { TGACTTTCTTITTCCTGCCTCACACTC }\end{array}$ & $66^{\circ} \mathrm{C}$ & $207 \mathrm{bp}$ \\
\hline
\end{tabular}


diseases. The mean age of the patients and control groups were in the range $55.2 \pm 5.7$ years and $55.1 \pm 6.8$ years, respectively. The subjects with urinary tract infection, pregnancy, inflammatory diseases, and cardiovascular-related problems as well as insufficient records came under the exclusion criteria.

\section{Isolation of DNA}

The blood samples were collected in ethylene-diamine tetra acetic acid (EDTA) vacutainer tubes. Five millilitres of whole blood was collected from the control and case subjects. Genomic DNA was isolated from the blood samples by Miller's method [19]. The quality and quantity of DNA were determined by the spectrophotometric method followed by agarose gel electrophoresis. Extracted DNA samples were stored at $-20{ }^{\circ} \mathrm{C}$ for genotyping purpose.

\section{Genotyping}

The genotyping of PTX3 (rs2305619 A>G) and PVT1 (rs2648875 G>A) polymorphisms were determined by Tetra-ARMS PCR using specific primers. The list of primers used for the amplification of rs2305619 and rs2648875 is shown in Table 1 . The primers designed to target the two SNPs are accessible at http://primer1. soton.ac.uk/primer1.html [20]. The PCR product sizes for the variant rs2305619 polymorphism were as follows: $439 \mathrm{bp}$ for two outer primers (control bands), $255 \mathrm{bp}$ for A allele, and 230 bp for $G$ allele (as shown in Fig. 1a). The PCR product sizes for the variant rs 2648875 polymorphism were as follows: $390 \mathrm{bp}$ for two outer primers (control bands), 239 bp for $\mathrm{G}$ allele, and $207 \mathrm{bp}$ for $\mathrm{A}$ allele (as shown in Fig. 2a). The amplification process was performed in a total volume of $15 \mu \mathrm{l}$ of the reaction mixture comprising of $2 \mu \mathrm{l}$ genomic DNA, $2 \mu \mathrm{l}$ of each inner primers, and $0.5 \mu$ of each outer primers, $5 \mu$ l of PCR Master Mix (Taq DNA Polymerase 2x Master mix RED) and $3 \mu \mathrm{l}$ of sterile water. The PCR reaction condition for the detection of the polymorphisms was $95{ }^{\circ} \mathrm{C}$ for $2 \mathrm{~min}$ followed up by 30 cycles, in addition to denaturation at $95{ }^{\circ} \mathrm{C}$ for $20 \mathrm{~s}$, annealing at $69{ }^{\circ} \mathrm{C}$ for $20 \mathrm{~s}, 72{ }^{\circ} \mathrm{C}$ for 1 min, and a final extension at $72{ }^{\circ} \mathrm{C}$ for 5 min to finish the extension of all PCR fragments. After the PCR process, the amplified products were analysed by $2 \%$

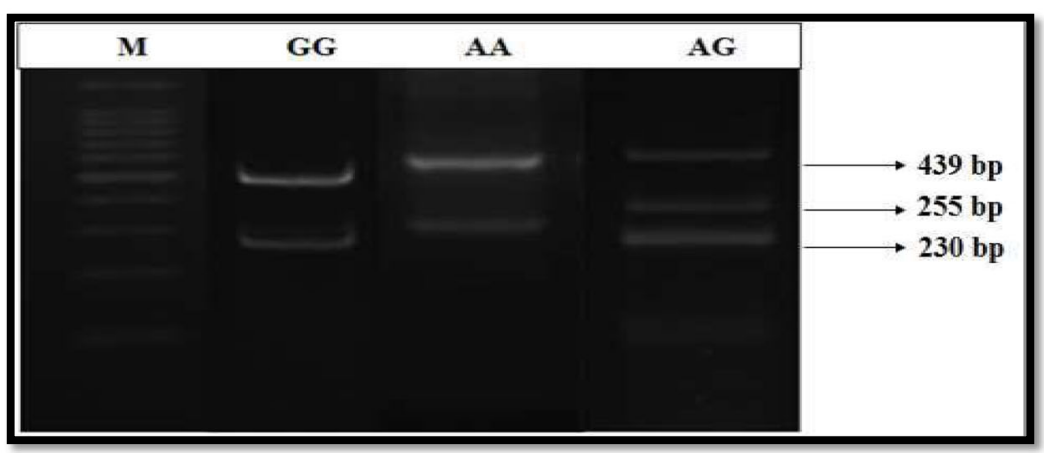

a: Gel picture representing $P T X 3 \mathrm{~A} / \mathrm{G}$ polymorphism. Lane 1: DNA Ladder (100-1500bp), Lane 2: Sample 1 (heterozygote), Lane 3: Sample 2 (heterozygote), Lane 4: Sample 3 (mutant homozygote)

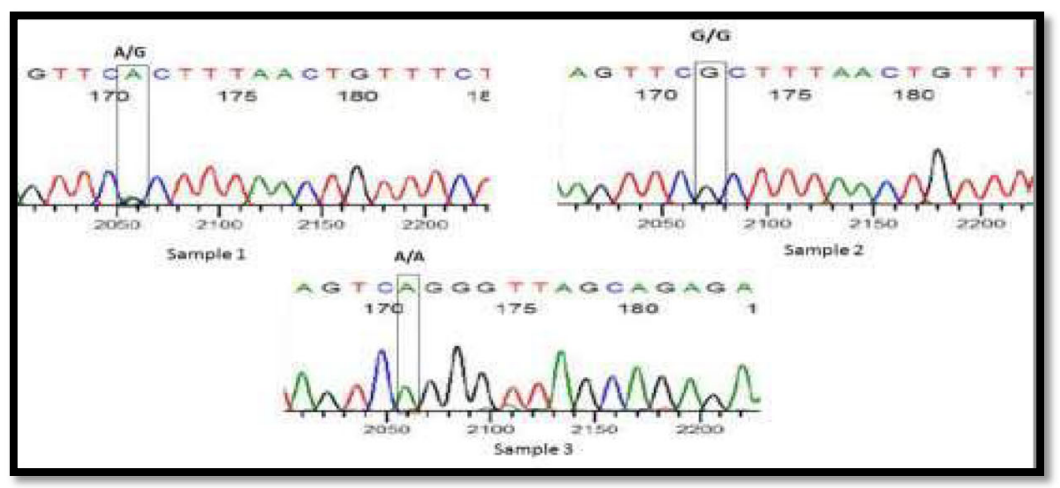

b: Sequencing results of $P T X 3 \mathrm{~A} / \mathrm{G}$ polymorphism

Fig. 1 a Gel picture representing PTX3 A/G polymorphism. Lane 1, DNA ladder (100-1500 bp); lane 2, sample 1 (heterozygote); lane 3, sample 2 (heterozygote); and lane 4, sample 3 (mutant homozygote). b Sequencing results of PTX3 A/G polymorphism 


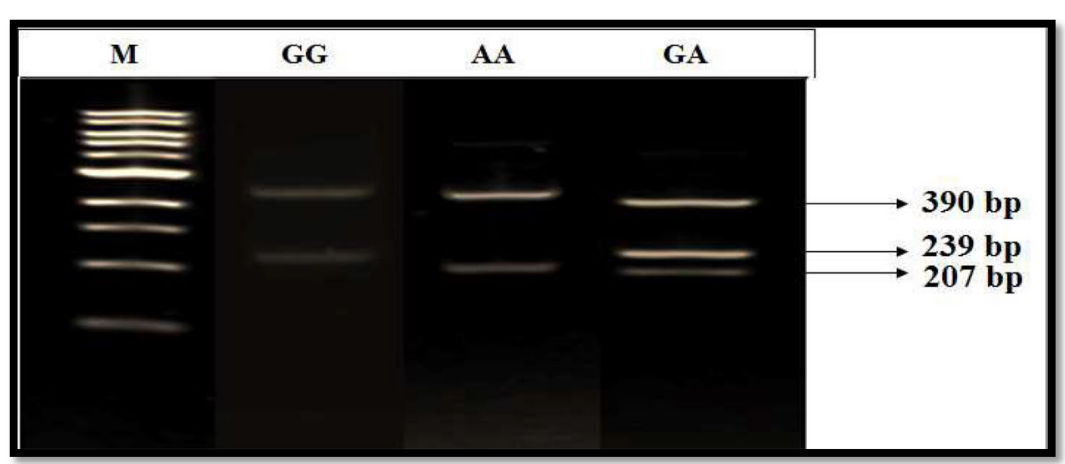

a: Gel picture representing PVT1 G/A polymorphism. Lane 1: DNA Ladder (100-1500bp),

Lane 2: Sample 1 (heterozygote), Lane 3: Sample 2 (heterozygote), Lane 4: Sample 3 (mutant homozygote)

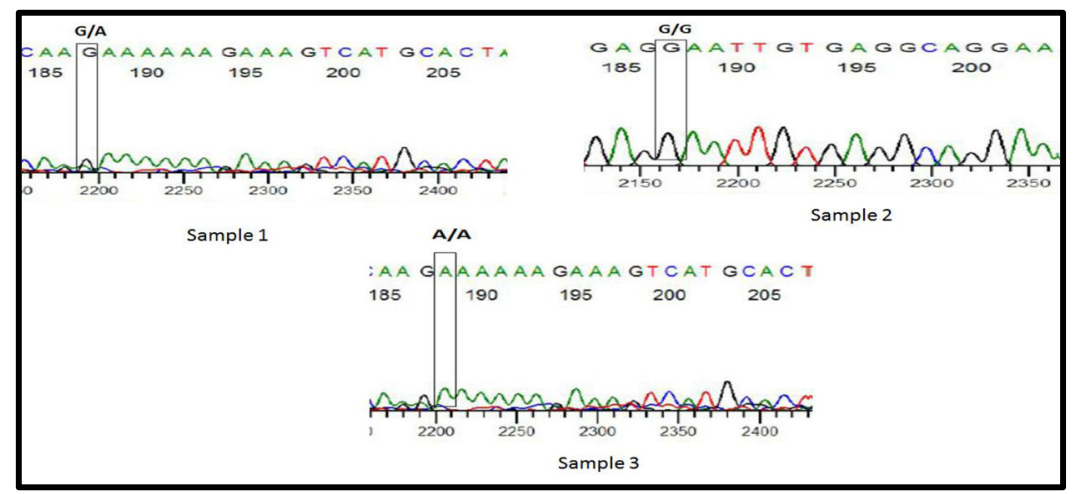

b: Sequencing results of $P V T 1 \mathrm{G} / \mathrm{A}$ polymorphism

Fig. 2 a Gel picture representing PVT1 G/A polymorphism. Lane 1, DNA ladder (100-1500 bp); lane 2, sample 1 (heterozygote); lane 3, sample 2 (heterozygote); and lane 4, sample 3 (mutant homozygote). b Sequencing results of PVT1 G/A polymorphism

agarose gel electrophoresis. In order to verify the results, the PCR products were randomly selected for sequencing analysis by the Sanger sequencing method (as shown in Figs. 1b and 2b).

\section{Statistical analysis}

The statistical analysis was performed by utilizing the SPSS version 21 software for Windows (IBM Analytic, USA). The significance of demographic information among the cases and healthy controls were done by Chisquare test. The association among the two genetic polymorphisms and its susceptibility to DKD was evaluated by the Odds ratio with their consistent 95\% confidence interval (CI) under four diverse genetic models which involved the co-dominant model, dominant model, recessive model, and the allelic model. The evaluation of different risk factors and the genotypes was attained by the odds ratio (OR) and 95\% confidence interval (CI) by using logistic regression analysis after adjusting the variables. A significant difference was assumed if the two- sided $p$ value $\leq 0.05$. Hardy-Weinberg equilibrium (HWE) was assessed by the $\chi^{2}$ test to determine the distribution of polymorphism among the controls.

\section{Results}

The demographic as well as biochemical characteristics of all the study groups included in the case-control study are shown in Table 2. There was a substantial increase in the levels of diabetes duration, blood glucose, protein creatinine ratio, systolic and diastolic blood pressure, and serum creatinine ratio in type 2 diabetic patients with DKD when compared with the other groups ( $p<$ 0.05 ) which thereby indicated the association of kidney disease in diabetes patients. However, the eGFR levels were found to be significantly lower than the T2DM patients without DKD and control subjects $(p=0.001)$. The levels of fasting and postprandial blood glucose, serum creatinine, LDL, SBP, and DBP were significantly $(p<0.05)$ greater in the T2DM patients with DKD group in comparison to the controls, whereas eGFR was 
observed to be reduced in the T2DM with DKD group than the other two groups $(p<0.05)$. Other biochemical parameters did not show any significant difference between the groups $(p>0.05)$. The allelic and genotypic distribution of PTX3 and PVT1 genetic polymorphisms among the diabetic patients without DKD and controls are presented in Table 3. The wild-type GG genotype of rs2305619 polymorphism and AA genotype of PVT1 polymorphism showed a high frequency but it was not statistically significant $(p>0.05)$. Likewise, no statistically significant difference in the genotype and allele frequency was observed among the diabetic patients without DKD and the control group in the different genetic models in both the genetic polymorphisms. Table 4 shows the allelic and genotypic distributions between the diabetic patients with DKD and the control group. The G allele and GG genotype of rs2305619 polymorphism was observed to be increased in the T2DM patients with DKD when compared to the other groups and it was also noted to be statistically significant $(p=0.04, p$ $=0.002)$, respectively, whereas no statistical significance was shown by the allelic and genotypic frequencies of rs2648875 polymorphism between the two groups. In addition, the distribution of allelic and genotypic frequencies of both the rs2305619 and rs2648875 polymorphisms did not show any statistical significance between the groups (Table 5).

In the logistic regression analysis, hypertension and the rs2305619 GA genotype showed an increase risk in the development of diabetic kidney disease whereas other risk factors did not show a positive association of DKD in the diabetic patients (Table 6). The clinical and biochemical parameters of type 2 diabetic patients with and without DKD in the genotypes of rs2305619 polymorphism are shown in Table 7. A significant difference was found between the diabetic patients with and without DKD and was seen by the increase in various parameters by the influence of the homo- and heterozygous frequencies. It was observed that despite the factors such as less duration of diabetes, high levels of glucose, HbA1c, protein creatinine ratio, systolic blood pressure, and diastolic blood pressure, the renal function deteriorated more rapidly in the diabetic patients with kidney disease, and the AG+GG heterozygous genotype when compared with the wild-type AA genotype. The frequency of the AG+GG genotype was considerably higher in diabetic patients with DKD when compared to those without DKD. Nevertheless, no significance was found

Table 2 Demographic and clinical characteristics of the study subjects

\begin{tabular}{|c|c|c|c|c|c|c|}
\hline Characteristics & $\begin{array}{l}\text { Control }(N= \\
140)\end{array}$ & $\begin{array}{l}\text { T2DM patients without DKD }(N= \\
\text { 140) }\end{array}$ & $\begin{array}{l}\text { T2DM patients with DKD }(N= \\
140)\end{array}$ & ${ }^{\dagger} p$ & $\begin{array}{l}{ }^{*} p \\
\text { value }\end{array}$ & $\begin{array}{l}{ }^{\ddagger} p \\
\text { value }\end{array}$ \\
\hline Gender (male to female ) & $67: 73$ & $69: 71$ & $64: 76$ & 0.78 & 0.49 & 0.68 \\
\hline Age (years) & $55.2 \pm 5.4$ & $57.4 \pm 3.1$ & $54.2 \pm 5.2$ & 0.03 & 0.16 & 0.22 \\
\hline $\mathrm{BMI}\left(\mathrm{Kg} / \mathrm{m}^{2}\right)$ & $24.2 \pm 3.2$ & $24.0 \pm 3.1$ & $24 \pm 2.9$ & 0.64 & 0.63 & 1.00 \\
\hline Diabetes duration (years) & - & $12 \pm 3.8$ & $13.4 \pm 4.0$ & - & - & $0.009^{*}$ \\
\hline $\begin{array}{l}\text { Fasting blood glucose (mg/ } \\
\mathrm{dL} \text { ) }\end{array}$ & $90.2 \pm 8.9$ & $162.6 \pm 9.8$ & $154.3 \pm 4.3$ & 0.001 & 0.001 & $0.001^{*}$ \\
\hline $\begin{array}{l}\text { Postprandial glucose (mg/ } \\
\mathrm{dL} \text { ) }\end{array}$ & $119.5 \pm 11.2$ & $165.6 \pm 13$ & $172.2 \pm 15.4$ & 0.001 & 0.001 & $0.001^{*}$ \\
\hline $\mathrm{HbA1c}(\%)$ & $5.6 \pm 1.5$ & $7.7 \pm 1.6$ & $7.9 \pm 2.1$ & 0.43 & 0.84 & 0.47 \\
\hline $\begin{array}{l}\text { Protein to creatinine ratio } \\
(\mathrm{mg} / \mathrm{g})\end{array}$ & $33.2 \pm 1.3$ & $52.1 \pm 1.5$ & $64.8 \pm 4.3$ & 0.001 & 0.001 & $0.001^{*}$ \\
\hline Serum creatinine (mg/dL) & $0.9 \pm 0.2$ & $0.9 \pm 0.31$ & $2.9 \pm 2.6$ & 0.57 & 0.001 & $0.001^{*}$ \\
\hline $\mathrm{HDL}(\mathrm{mg} / \mathrm{dl})$ & $48 \pm 14.9$ & $46.1 \pm 15.4$ & $45.1 \pm 15.2$ & 0.35 & 0.15 & 0.63 \\
\hline LDL (mg/dl) & $93.8 \pm 32$ & $95.3 \pm 29.9$ & $97.5 \pm 28.5$ & 0.72 & 0.37 & 0.58 \\
\hline eGFR (ml/min) & $131.9 \pm 15.1$ & $108.1 \pm 11.5$ & $54.9 \pm 12.5$ & 0.001 & 0.001 & $0.001^{*}$ \\
\hline $\mathrm{SBP}(\mathrm{mmHg})$ & $112 \pm 6.5$ & $134.0 \pm 6.9$ & $144.5 \pm 4.5$ & 0.001 & 0.001 & $0.001^{*}$ \\
\hline $\mathrm{DBP}(\mathrm{mmHg})$ & $74.3 \pm 5.2$ & $91.2 \pm 5.3$ & $106.7 \pm 3.5$ & 0.001 & 0.001 & $0.001^{*}$ \\
\hline \multicolumn{7}{|l|}{ Smoking } \\
\hline Yes & 56 & 64 & 59 & & & \\
\hline No & 84 & 76 & 81 & 0.21 & 0.63 & 0.44 \\
\hline
\end{tabular}

$B M I$ body mass index, HbA1c glycosylated haemoglobin, eGFR estimated glomerular filtration rate, SBP systolic blood pressure, DBP diastolic blood pressure ${ }^{\dagger}$ Comparison between T2DM patients without DKD group with control group

${ }^{\ddagger}$ Comparison between T2DM patients with DKD group with control group

${ }^{\ddagger}$ Comparison between T2DM patients without and with DKD group

*Statistical significance 
Table 3 Association of PTX3 and PVT1 gene polymorphism in T2DM patients without DKD and controls

\begin{tabular}{|c|c|c|c|c|c|}
\hline Gene (rsID) & Models & T2DM patients without DKD & Controls & Odds ratio $(95 \% \mathrm{Cl})$ & $P$ value \\
\hline \multirow[t]{11}{*}{ PTX3 rs2305619 (A/G) } & Co-dominant model & & & & \\
\hline & AA & 78 & 86 & Ref & - \\
\hline & AG & 44 & 47 & $0.90(0.54-1.49)$ & 0.70 \\
\hline & GG & 18 & 7 & $2.80(1.13-6.94)$ & $0.02^{*}$ \\
\hline & Dominant model & & & & \\
\hline & $A G+G G$ vs $A A$ & - & - & $1.20(0.70-2.02)$ & 0.49 \\
\hline & Recessive model & & & & \\
\hline & $\mathrm{GG}$ vs $\mathrm{AA}+\mathrm{AG}$ & - & - & $0.39(0.14-1.01)$ & 0.06 \\
\hline & Allelic model & & & & \\
\hline & A & 197 & 211 & Ref & - \\
\hline & G & 83 & 69 & $0.77(0.53-1.12)$ & 0.18 \\
\hline \multirow[t]{11}{*}{ PVT1 rs2648875 (G/A) } & Co-dominant model & & & & \\
\hline & GG & 82 & 84 & Ref & - \\
\hline & GA & 39 & 46 & $0.78(0.47-1.31)$ & 0.36 \\
\hline & AA & 19 & 10 & $2.04(0.91-4.56)$ & 0.08 \\
\hline & Dominant model & & & & \\
\hline & $\mathrm{GA}+\mathrm{AA}$ vs $\mathrm{GG}$ & - & - & $1.07(0.62-1.82)$ & 0.78 \\
\hline & Recessive model & & & & \\
\hline & $A A$ vs $G G+G A$ & - & - & $0.42(0.16-1.10)$ & 0.07 \\
\hline & Allelic model & & & & \\
\hline & G & 199 & 209 & Ref & - \\
\hline & A & 59 & 69 & $1.11(0.74-1.65)$ & 0.59 \\
\hline
\end{tabular}

Ref reference, $O R$ odds ratio, $\mathrm{Cl}$ confidence interval

${ }^{*} p$ value $<0.05$ considered to be significant

among the other factors such as age, gender, BMI, serum creatinine, eGFR, and smoking, whereas the T2DM patients with DKD and rs2648875 polymorphism did not show any significance in the clinical as well as the biochemical characteristics (data not shown).

\section{Discussion}

The current study has examined the role of PTX3 gene variants and $P V T 1$ variants with the increased possibility of progressing to diabetic kidney disease in type 2 diabetic patients. This investigation was carried out at Chettinad Hospital and Research Institute a tertiary care hospital by comparing three different groups such as (a) T2DM without DKD vs controls, (b) T2DM with DKD vs controls, and (c) T2DM with DKD vs T2DM without DKD. The results have shown a strong association between diabetic patients with DKD $(p$ value $<0.05)$ signifying that PTX3 variants can be a possible risk factor in the progression of diabetic kidney disease in type 2 diabetic patients. Further, no significant results were obtained among the PVT1 variants and DKD in the study population.
In our study, statistical analysis of genotypic frequencies for the PTX3 (rs2305619) polymorphism revealed substantial variation between T2DM patients with DKD and controls in the examined population. The statistical analysis among the T2DM with and without DKD showed no statistically significant difference among the two groups. Variant genotype of PTX3 (GG) increased the levels of PTX3 which play a protective role in the disease pathogenesis of the South Indian population. These results are in agreement with the findings of a previously published study where they found PTX3 polymorphisms were linked with a high risk of DN in Chinese patients with type 2 diabetes [11].

Our study also revealed that some of the clinical parameters such as diabetic duration, blood glucose levels, HbA1c, protein creatinine ratio, systolic, and diastolic blood pressure were found to be considerably higher in the abovementioned diabetic-related complications demonstrating an effect of the PTX3 polymorphism for further advancement of diabetic kidney disease in diabetic patients. Another study has reported that the elevated levels of pentraxin 3 seems to be a potential biomarker for the inflammatory status and can be also proposed as 
Table 4 Association of PTX3 and PVT1 gene polymorphism in T2DM patients with DKD and controls

\begin{tabular}{|c|c|c|c|c|c|}
\hline Gene (rsID) & Models & T2DM patients with DKD & Controls & Odds ratio $(95 \% \mathrm{Cl})$ & $P$ value \\
\hline \multirow[t]{11}{*}{ PTX3 rs2305619 (A/G) } & Co-dominant model & & & & \\
\hline & AA & 75 & 85 & Ref & - \\
\hline & AG & 29 & 35 & $1.27(0.72-2.23)$ & 0.39 \\
\hline & GG & 36 & 20 & $2.07(1.13-3.80)$ & $0.01^{*}$ \\
\hline & Dominant model & & & & \\
\hline & $A G+G G$ vs $A A$ & - & - & $1.16(0.67-2.01)$ & 0.58 \\
\hline & Recessive model & & & & \\
\hline & $\mathrm{GG}$ vs $\mathrm{AA}+\mathrm{AG}$ & - & - & $0.22(0.08-0.59)$ & $0.002^{*}$ \\
\hline & Allelic model & & & & \\
\hline & A & 191 & 216 & Ref & - \\
\hline & G & 89 & 64 & $0.63(0.43 .0-0.92)$ & $0.01^{*}$ \\
\hline \multirow[t]{11}{*}{ PVT1 rs2648875 (G/A) } & Co-dominant model & & & & \\
\hline & GG & 77 & 84 & Ref & - \\
\hline & GA & 38 & 36 & $1.07(0.63-1.83)$ & 0.78 \\
\hline & $A A$ & 24 & 20 & $1.24(0.65-2.36)$ & 0.51 \\
\hline & Dominant model & & & & \\
\hline & $\mathrm{GA}+\mathrm{AA}$ vs $\mathrm{GG}$ & - & - & $1.25(0.73-2.11)$ & 0.40 \\
\hline & Recessive model & & & & \\
\hline & $A A$ vs $G G+G A$ & - & - & $0.61(0.22-1.60)$ & 0.32 \\
\hline & Allelic model & & & & \\
\hline & G & 194 & 214 & Ref & - \\
\hline & A & 86 & 66 & $0.69(0.47-1.01)$ & 0.06 \\
\hline
\end{tabular}

Ref reference, $O R$ odds ratio, $\mathrm{Cl}$ confidence interval

${ }^{*} p$ value $<0.05$ considered to be significant

a predictor of chronic kidney disease patients [21]. The levels of PTX3 mRNA were also revealed to be linked with the endothelial cell function in patients with chronic kidney disease [22]. It should be also noted that the PTX3 gene is located in the chromosome 3 at q25 which is as well recognized as the main locus which is predisposed to $\mathrm{DN}$ in both type 1 and type 2 diabetic patients [21, 23]. Another study by El Naidany et al., 2020, have reported that GG genotypes of rs2305619 (A/G) polymorphism along with increased serum PTX3 levels are found to be major factor of $\mathrm{DN}$ in diabetic patients [24].

In the current investigation, statistical analyses of genotypic frequencies for the PVT1 (rs2648875) showed no significant difference between T2DM patients with and without DKD when compared to the controls in the examined population. Similar to these findings, a previous study has reported that these polymorphisms are not associated with end-stage renal diseases in type 2 diabetes among Pima Indians [25]. Yet another study has investigated the link between the variants of PVT1 gene with end-stage renal disease in ethnically diverse populations in diabetic patients [12]. Their findings have indicated that PVT1 is found to be expressed abundantly in the renal cells and that is observed to have a possible role in the metabolic dysfunction of renal tissues which further proceeds in the development of kidney-related complications specially in patients with diabetes. A GWAS study has also reported PVT1 polymorphism rs2648875 (G/A) to be associated with diabetic kidney disease [26].

In our study, we also studied the statistical analysis between the genotypes of PVT1 genetic polymorphism and clinical parameters. The results indicated a nonsignificant relation between the genotypes and the parameters. These are contrary to the findings where they found a 5-fold increase in the expression levels of PVT1 specifically because of hyperglycemic levels which further shown an effect of glucose on the regulation of PVT1 [27]. Microalbuminuria is proved to detect kidney disease like diabetic nephropathy by a urine dipstick diagnostic method [28]. Genetic association studies is known to be helpful to find the related genes which 
Table 5 Association of PTX3 and PVT1 gene polymorphism in T2DM patients with and without DKD

\begin{tabular}{|c|c|c|c|c|c|}
\hline Gene (rsID) & Models & T2DM patients with DKD & T2DM patients without DKD & Odds ratio $(95 \% \mathrm{Cl})$ & $P$ value \\
\hline \multirow[t]{11}{*}{ PTX3 rs2305619 (A/G) } & \multicolumn{5}{|l|}{ Co-dominant model } \\
\hline & AA & 72 & 70 & Ref & - \\
\hline & $A G$ & 25 & 34 & $0.67(0.37-1.21)$ & 0.18 \\
\hline & GG & 43 & 36 & $1.28(0.75-2.15)$ & 0.35 \\
\hline & \multicolumn{5}{|l|}{ Dominant model } \\
\hline & $A G+G G$ vs $A A$ & - & - & $0.96(0.56-1.62)$ & 0.89 \\
\hline & \multicolumn{5}{|l|}{ Recessive model } \\
\hline & GG vs $A A+A G$ & - & - & $0.58(0.28-1.20)$ & 0.15 \\
\hline & \multicolumn{5}{|l|}{ Allelic model } \\
\hline & A & 188 & 195 & Ref & - \\
\hline & G & 92 & 85 & $0.89(0.62-1.27)$ & 0.52 \\
\hline \multirow[t]{11}{*}{ PVT1 rs2648875 (G/A) } & \multicolumn{5}{|l|}{ Co-dominant model } \\
\hline & GG & 89 & 85 & Ref & - \\
\hline & GA & 43 & 40 & $1.41(0.79-2.50)$ & 0.24 \\
\hline & AA & 8 & 15 & $1.10(0.66-1.85)$ & 0.69 \\
\hline & \multicolumn{5}{|l|}{ Dominant model } \\
\hline & $\mathrm{GA}+\mathrm{AA}$ vs $\mathrm{GG}$ & - & - & $1.16(0.67-1.92)$ & 0.58 \\
\hline & \multicolumn{5}{|l|}{ Recessive model } \\
\hline & $A A$ vs $G G+G A$ & - & - & $1.42(0.62-3.21)$ & 0.40 \\
\hline & \multicolumn{5}{|l|}{ Allelic model } \\
\hline & G & 184 & 186 & Ref & - \\
\hline & $A$ & 96 & 94 & $0.96(0.68-1.37)$ & 0.85 \\
\hline
\end{tabular}

Ref reference, $\mathrm{OR}$ odds ratio, $\mathrm{Cl}$ confidence interval

Table 6 Logistic regression analysis for the association among diabetic kidney disease, genetic variants, and confounding risk factors in diabetes mellitus patients

\begin{tabular}{llll}
\hline Variables & Odds ratio & $\mathbf{9 5 \% ~ C l}$ & $\boldsymbol{P}$ value \\
\hline Age & 1.06 & $0.95-1.05$ & 0.84 \\
BMI & 1.08 & $0.96-1.23$ & 0.20 \\
Diabetes duration (years) & 0.72 & $0.43-0.96$ & 0.46 \\
FBG (mg/dl) & 0.99 & $0.98-1.02$ & 0.85 \\
PPG (mg/dl) & 1.00 & $0.99-1.02$ & 0.26 \\
Hypertension & 1.25 & $0.45-2.43$ & $0.01^{*}$ \\
Smoking & 0.47 & $0.35-0.85$ & 0.63 \\
Serum creatinine (mg/dl) & 0.78 & $0.48-1.34$ & 0.36 \\
eGFR (ml/min) & 1.47 & $0.75-2.52$ & 0.14 \\
Protein to creatinine ratio (mg/g) & 1.53 & $0.89-3.00$ & 0.12 \\
rs2305619 genotype (GA) & 1.85 & $1.13-3.03$ & $0.01^{*}$ \\
rs2648875 genotype (AG) & 0.70 & $0.43-1.13$ & 0.14 \\
\hline
\end{tabular}

$B M I$ body mass index, $F B G$ fasting blood glucose, $P P G$ postprandial blood glucose, eGFR estimated glomerular filtration rate, OR odds ratio, $\mathrm{Cl}$ confidence interval

${ }^{*} p$ value $<0.05$ considered to be significant
Table 7 Characteristics and clinical parameters of PTX3 genotypes

\begin{tabular}{|c|c|c|c|}
\hline Clinical characteristics & AA & AG+GG & $P$ value \\
\hline Number & 161 & 119 & - \\
\hline Age (years) & $55.2 \pm 0.62$ & $55.8 \pm 0.34$ & 0.15 \\
\hline Gender (male/female) & $86 / 101$ & $59 / 78$ & 0.60 \\
\hline BMI $\left(\mathrm{Kg} / \mathrm{m}^{2}\right)$ & $24.1 \pm 0.94$ & $24.08 \pm 0.75$ & 0.98 \\
\hline Diabetes duration (years) & $15 \pm 0.66$ & $15.8 \pm 0.71$ & $0.01 *$ \\
\hline Fasting blood glucose (mg/dL) & $136.7 \pm 0.78$ & $140.9 \pm 2.08$ & $0.01 *$ \\
\hline Post prandial glucose (mg/dL) & $122.5 \pm 1.03$ & $124.7 \pm 0.98$ & $<0.001^{*}$ \\
\hline HbA1c (\%) & $7.1 \pm 1.4$ & $8.9 \pm 0.21$ & $<0.001^{*}$ \\
\hline Serum creatinine (mg/dL) & $75.9 \pm 0.94$ & $76.2 \pm 1.3$ & 0.10 \\
\hline eGFR (ml/min) & $74.8 \pm 0.94$ & $75.3 \pm 0.55$ & 0.10 \\
\hline Protein to creatinine ratio $(\mathrm{mg} / \mathrm{g})$ & $47.1 \pm 2.6$ & $59.2 \pm 1.2$ & $<0.001^{*}$ \\
\hline Smoking & 78 & 84 & 0.48 \\
\hline Systolic blood pressure (mmHg) & $116 \pm 0.8$ & $122.1 \pm 0.50$ & $<0.001 *$ \\
\hline Diastolic blood pressure $(\mathrm{mmHg})$ & $76.2 \pm 0.44$ & $77.3 \pm 0.85$ & $0.009^{*}$ \\
\hline
\end{tabular}


predispose to a disease. A previous meta-analysis study by Varghese et al., 2019 has proved the positive link of NOS3 (nitric oxide synthase 3 ) and the negative association of TGF $\beta 1$ genes with DN [29].

The differences among our results with other research findings would be due to variances in the populations, though these outcomes alone will not be inevitably sufficient to get to final evidence mostly because of the small sample size of the studied population. Still, it could be considered strong evidence with significant data on the effect of the investigated genetic variants on the susceptibility to diabetic kidney disease.

\section{Conclusions}

In conclusion, this case-control study exhibits a significant association of PTX3 gene variant (rs2305619) in the progression of DKD in type 2 diabetic patients. This investigation further reported a non-significant association of PVT1 gene variant (rs2648875) in the development of diabetic kidney disease in the studied population. Additionally, it is necessary to enlarge the sample size and combine it with other risk factors such as lifestyle changes in order to increase the understanding of more issues influencing the advancement of diabetic kidney disease.

\section{Abbreviations}

DKD: Diabetic kidney disease; DM: Diabetes mellitus; ACR: Albumin creatinine ratio; PTX3: Pentraxin 3; PVT1: Plasmacytoma variant translocation 1 gene; TGFß1: Transforming growth factor-beta 1; KDOQI: Kidney Disease Outcomes Quality Initiative; EDTA: Ethylene-diamine tetra acetic acid; Tetra-ARMS PCR: Tetra-primer amplification refractory mutation system PCR; SPSS: Statistical Package for Social Sciences; HWE: Hardy-Weinberg equilibrium

\section{Acknowledgements}

The authors were thankful to all the subjects who have taken part in this study. The authors would like to thank the Prof. Ram Murugesan, Director Research, Chettinad Academy of Research and Education for his support to perform the study. We would like to express our thanks to Mrs. Kurunchi Divya for her support in protocol standardization.

\section{Authors' contributions}

The first author (SV) carried out the genotyping studies and interpretation of the data, performed statistical analysis, and drafted the manuscript. GKS revised and final approval of the draft of the manuscript. Both the authors have read and approved the manuscript for the submission.

\section{Funding}

This research work is not funded.

\section{Availability of data and materials}

The datasets analysed during the current study are available with the corresponding author on reasonable request.

\section{Declarations}

\section{Ethics approval and consent to participate}

The current study was approved by the Institution's Ethical Committee of Chettinad Academy of Research and Education on 23 October 2017 with an approval number (IHEC No. 366/IHEC/10-17). A written informed consent form was attained from all participants involved in the study.

\section{Consent for publication}

The consent for publication was obtained from all the participants enrolled in the study.

\section{Competing interests}

The authors declare that they have no competing interest.

Received: 1 April 2021 Accepted: 6 May 2021

Published online: 01 June 2021

\section{References}

1. Alberti KG, Zimmet P (2013) Epidemiology: global burden of disease-where does diabetes mellitus fit in? Nat Rev Endocrinol 9(5):258260. https://doi.org/10.1038/nrendo.2013.54

2. Aldukhayel A (2017) Prevalence of diabetic nephropathy among type 2 diabetic patients in some of the Arab countries. Int J Health Sci 11(1):1

3. Collins AJ, Foley R, Herzog C, Chavers B, Gilbertson D, Ishani A, Kasiske B, Liu J, Mau LW, McBean M, Murray A (2008) United States Renal Data System 2007 annual data report abstract. Am J Kidney Dis 51(1):6-7

4. Gross UL, De Azevedo MJ, Silveiro SP, Canani LH, Caramori ML, Zelmanovitz T (2005) Diabetic nephropathy: diagnosis, prevention, and treatment. Diabetes Care 28(1):164-176. https://doi.org/10.2337/diacare.28.1.164

5. Forbes JM, Cooper ME (2013) Mechanisms of diabetic complications. Physio Rev 93(1):137-188. https://doi.org/10.1152/physrev.00045.2011

6. Gall MA, Rossing P, Skøtt P, Damsbo P, Vaag A, Bech K, Dejgaard A Lauritzen M, Lauritzen E, Hougaard P, Beck-Nielsen H (1991) Prevalence of micro-and macroalbuminuria, arterial hypertension, retinopathy and large vessel disease in European type 2 (non-insulin-dependent) diabetic patients. Diabetologia. 34(9):655-661. https://doi.org/10.1007/BF00400995

7. Nauta AJ, De Haij S, Bottazzi B, Mantovani A, Borrias MC, Aten JA, Rastaldi MP, Daha MR, Van Kooten C, Roos A (2005) Human renal epithelial cells produce the long pentraxin PTX3. Kidney Int 67(2):543-553. https://doi.org/1 0.1111/j.1523-1755.2005.67111.X

8. Uzun S, Ozari M, Gursu M, Karadag S, Behlul A, Sari S, Koldas M, Demir S, Karaali Z, Ozturk S (2016) Changes in the inflammatory markers with advancing stages of diabetic nephropathy and the role of pentraxin-3. Ren Fail 38(8):1193-1198. https://doi.org/10.1080/0886022X.2016.1209031

9. Carmo RF, Aroucha D, Vasconcelos LR, Pereira LM, Moura P, Cavalcanti MS (2016) Genetic variation in PTX 3 and plasma levels associated with hepatocellular carcinoma in patients with HCV. J Viral Hepat 23(2):116-122. https://doi.org/10.1111/jvh.12472

10. Meuwese CL, Carrero JJ, Stenvinkel P (2011) Recent insights in inflammation-associated wasting in patients with chronic kidney disease. Hemodialysis 171:120-6. https://doi.org/10.1159/000327228

11. Zhu H, Yu W, Xie Y, Zhang H, Bi Y, Zhu D (2017) Association of pentraxin 3 gene polymorphisms with susceptibility to diabetic nephropathy. Med Sci Monit 23:428-436. https://doi.org/10.12659/MSM.902783

12. Alvarez ML, DiStefano JK (2011) Functional characterization of the plasmacytoma variant translocation 1 gene (PVT1) in diabetic nephropathy. PLoS One 6(4):e18671. https://doi.org/10.1371/journal.pone.0018671

13. Olesen R, Wejse C, Velez DR, Bisseye C, Sodemann M, Aaby P, Rabna P, Worwui A, Chapman H, Diatta M, Adegbola RA (2007) DC-SIGN (CD209), pentraxin 3 and vitamin D receptor gene variants associate with pulmonary tuberculosis risk in West Africans. Genes Immun 8(6):456-467. https://doi. org/10.1038/sj.gene.6364410

14. Shtivelman E, Bishop JM (1989) The PVT gene frequently amplifies with MYC in tumor cells. Mol Cell Biol 9(3):1148-1154. https://doi.org/10.1128/MCB. 9.3.1148

15. Alvarez ML, Khosroheidari M, Eddy E, Kiefer J (2013) Role of microRNA 1207$5 \mathrm{P}$ and its host gene, the long non-coding RNA Pvt1, as mediators of extracellular matrix accumulation in the kidney: implications for diabetic nephropathy. PLoS One 8(10):e77468. https://doi.org/10.1371/journal.pone. 0077468

16. Hanson RL, Craig DW, Millis MP, Yeatts KA, Kobes S, Pearson JV, Lee AM, Knowler WC, Nelson RG, Wolford JK (2007) Identification of PVT1 as a candidate gene for end-stage renal disease in type 2 diabetes using a pooling-based genome-wide single nucleotide polymorphism association study. Diabetes. 56(4):975-983. https://doi.org/10.2337/db06-1072

17. American Diabetes Association (2015) Standards of medical care in diabetes - 2015 abridged for primary care providers. Clin Diabetes 33(2):97 
18. Foundation NK (2012) KDOQI clinical practice guideline for diabetes and CKD: 2012 update. Am J Kidney Dis 60(5):850-886

19. Miller SA, Dykes DD, Polesky HF (1988) A simple salting out procedure for extracting DNA from human nucleated cells. Nucleic Acids Res 16(3):1215. https://doi.org/10.1093/nar/16.3.1215

20. Ye S, Dhillon S, Ke X, Collins AR, Day IN (2001) An efficient procedure for genotyping single nucleotide polymorphisms. Nucleic Acids Res 29(17):e88

21. Diamond JM, Meyer NJ, Feng R, Rushefski M, Lederer DJ, Kawut SM, Lee JC, Cantu E, Shah RJ, Lama VN, Bhorade S (2012) Variation in PTX3 is associated with primary graft dysfunction after lung transplantation. Am J Respir Crit Care Med 186(6):546-552. https://doi.org/10.1164/rccm.201204-06920C

22. Witasp A, Rydén M, Carrero JJ, Qureshi AR, Nordfors L, Näslund E, Hammarqvist F, Arefin S, Kublickiene K, Stenvinkel P (2013) Elevated circulating levels and tissue expression of pentraxin 3 in uremia: a reflection of endothelial dysfunction. PLoS One 8(5):e63493. https://doi.org/10.1371/ journal.pone.0063493

23. Shaza AM, Rozina G, Izham MM, Azhar SS (2005) Dialysis for end stage renal disease: a descriptive study in Penang Hospital. Med J Malaysia 60(3):320

24. El Naidany SS, Zahran E, Abd El Gayed EM (2020) Association of Pentraxin 3 rs2305619 (A/G) gene polymorphism and its serum level with the risk of nephropathy in type II diabetic patients. Gene Reports 20:100670

25. Bowden DW, Colicigno CJ, Langefeld CD, Sale MM, Williams A, Anderson PJ, Rich SS, Freedman BI (2004) A genome scan for diabetic nephropathy in African Americans. Kidney Int 66(4):1517-1526. https://doi.org/10.1111/j.1 523-1755.2004.00915.x

26. Harvest F. Gu, (2019) Genetic and Epigenetic Studies in Diabetic Kidney Disease. Front Genet 10

27. Millis MP, Bowen D, Kingsley C, Watanabe RM, Wolford JK (2007) Variants in the plasmacytoma variant translocation gene (PVT1) are associated with end-stage renal disease attributed to type 1 diabetes. Diabetes. 56(12):30273032. https://doi.org/10.2337/db07-0675

28. Prevalence of micro albuminuria and diagnostic accuracy of urine dipstick for the screening of diabetic nephropathy in type 2 diabetes patients

29. Sindhu Varghese, Gowtham Kumar Subburaj (2019) Association between genetic variants of NOS3, TGF- $\beta$ and susceptibility of diabetic nephropathy: A metaanalysis. Meta Gene 21:100573

\section{Publisher's Note}

Springer Nature remains neutral with regard to jurisdictional claims in published maps and institutional affiliations.

\section{Submit your manuscript to a SpringerOpen ${ }^{\circ}$ journal and benefit from:}

- Convenient online submission

- Rigorous peer review

- Open access: articles freely available online

High visibility within the field

- Retaining the copyright to your article

Submit your next manuscript at $\boldsymbol{\nabla}$ springeropen.com 